Hobbs, R.W., Huber, B.T., Bogus, K.A., and the Expedition 369 Scientists Proceedings of the International Ocean Discovery Program Volume 369 publications.iodp.org

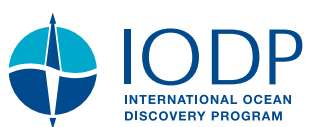

Check for updates Contents

\section{Data report: X-ray diffraction mineralogy of a volcanic sequence at Site U1513 (Naturaliste Plateau), IODP Expedition $369^{1}$}

Laurent Riquier, ${ }^{2}$ Eun Young Lee, ${ }^{3}$ and Maria Luisa G. Tejada ${ }^{4}$

Keywords: International Ocean Discovery Program, IODP, JOIDES Resolution, Expedition 369, Site U1513, Australian Cretaceous Climate and Tectonics, volcanic succession, basalt, volcaniclastics, X-ray diffraction, alteration, Naturaliste Plateau
1 Abstract
1 Introduction
1 Materials and methods
2 Results
3 Acknowledgments
3 References

\begin{abstract}
International Ocean Discovery Program Expedition 369 recovered a volcanic sequence (Lithostratigraphic Unit VI) at Site U1513 on the eastern Naturaliste Plateau, offshore southwest Australia. We report here the mineralogical composition of the $82.2 \mathrm{~m}$ thick volcanic sequence cored in Holes U1513D (24 samples) and U1513E (20 samples) based on X-ray diffraction analysis. The primary minerals preserved in basalt flows and dolerite dikes are plagioclase feldspar and pyroxene, whereas the original olivines have been mostly transformed into secondary phases. Increasing alteration intensity is accompanied by higher amounts of clay minerals (chlorite, kaolinite, interstratified smectite-chlorite, and smectite), iron oxides (magnetite, hematite, and goethite), and likely other secondary minerals associated with serpentinization and sericitization processes. The fine-grained matrix of the volcaniclastic beds contains abundant clay minerals (mainly kaolinite) accompanied by intense hematization.
\end{abstract}

\section{Introduction}

Site U1513 was drilled during International Ocean Discovery Program (IODP) Expedition 369 in 2017. This site is located in the eastern flank of the submarine Naturaliste Plateau on the southwest Australian rifted continental margin (Figure F1A). The volcanic sequence (Lithostratigraphic Unit VI) (Figure F1B) was cored in Holes U1513D $\left(33^{\circ} 47.6196^{\prime} \mathrm{S}, 1^{\circ} 12^{\circ} 29.1339^{\prime} \mathrm{E}\right)$ and U1513E $\left(33^{\circ} 47.6190^{\prime} \mathrm{S}, 112^{\circ} 29.1204^{\prime} \mathrm{E}\right)$ (Huber et al., 2019b). Site U1513 is very close to Deep Sea Drilling Project (DSDP) Leg 26 Site 258 (33⒋69'S, $112^{\circ} 28.42^{\prime}$ E) (Shipboard Scientific Party, 1974), which only partially cored the volcaniclastic-rich sedimentary sequence (Lithostratigraphic Unit V) (Lee et al., 2020) overlying the volcanic sequence at Site U1513 (Figure F1B). The $82.2 \mathrm{~m}$ thick volcanic se- quence was cored between 690.28 and $756.70 \mathrm{~m}$ core depth below seafloor, Method A (CSF-A) in Hole U1513D and between 688.07 and $770.27 \mathrm{~m}$ CSF-A in Hole U1513E. The volcanic sequence is composed of nine units consisting of several basalt flows and volcaniclastic beds cut by multiple dolerite dikes (Figure F1C). In this data report, based on X-ray diffraction (XRD), we present the identification of minerals in the volcanic rocks that represent primary igneous and secondary alteration minerals.

\section{Materials and methods}

During and after Expedition 369, lithology, mineralogical composition and assemblage, alteration intensity, and other features were described for the volcanic sequence at Site U1513 (Huber et al., 2019b; Tejada et al., 2020). The core descriptions were supplemented with data from whole-rock XRD mineral identification on 44 core samples (24 samples from Hole U1513D and 20 samples from Hole U1513E) that were selected based on what were deemed the most suitable and representative lithologic components of the cores.

The 24 core samples from Hole U1513D were analyzed on board during the expedition. The whole-rock XRD analysis was conducted using a Bruker D4 Endeavor diffractometer mounted with a Vantec-1 detector using nickel-filtered $\mathrm{CuK \alpha}$ radiation. The standard locked coupled scan was conducted with a voltage of $40 \mathrm{kV}$, current of $40 \mathrm{~mA}$, and measurement range of $4^{\circ}-70^{\circ} 2 \theta$ (Huber et al., 2019a). The XRD data of core samples from Hole U1513D are available at http://web.iodp.tamu.edu/LORE. The 20 core samples from Hole U1513E were analyzed after the expedition at the Korea Basic Science Institute (KBSI) Gwangju Center. The whole-rock XRD analysis was conducted using a Bruker D8 Advance diffractometer with a Lynxeye detector using nickel-filtered $\mathrm{CuK} \alpha$ radiation. The standard locked coupled scan was conducted with a

\footnotetext{
'Riquier, L., Lee, E.Y., and Tejada, M.L.G., 2021. Data report: X-ray diffraction mineralogy of a volcanic sequence at Site U1513 (Naturaliste Plateau), IODP Expedition 369. In Hobbs, R.W., Huber, B.T., Bogus, K.A., and the Expedition 369 Scientists, Australia Cretaceous Climate and Tectonics. Proceedings of the International Ocean Discovery Program, 369: College Station, TX (International Ocean Discovery Program). https://doi.org/10.14379/iodp.proc.369.205.2021

${ }^{2}$ Institut des Sciences de la Terre de Paris (ISTeP), Sorbonne University, France. Iaurent.riquier@sorbonne-universite.fr

${ }^{3}$ Faculty of Earth System and Environmental Sciences, Chonnam National University, Republic of Korea.

${ }^{4}$ Institute of Marine Geodynamics (IMG), Japan Agency for Marine-Earth Science and Technology, Japan.

MS 369-205: Received 17 November 2020 · Accepted 15 May 2021 . Published 31 August 2021

This work is distributed under the Creative Commons Attribution 4.0 International (CC BY 4.0) license. (cc) B
} 
Figure F1. A. Map of the Naturaliste Plateau offshore southwest Australia showing the location of IODP Expedition 369 Site U1513 and DSDP Leg 26 Site 258. Bathymetric contour interval $=500 \mathrm{~m}$; Naturaliste Plateau is defined approximately by the $4000 \mathrm{~m}$ contour (modified from Borissova, 2002). B. Lithostratigraphy at Site U1513 (Huber et al., 2019b). C. Volcanic units of Holes U1513D and U1513E. Units are distinguished by changes in dominant lithology, texture, color, and physical properties and by the presence of faults, chilled margins, and baked contacts (modified from Tejada et al., 2020).

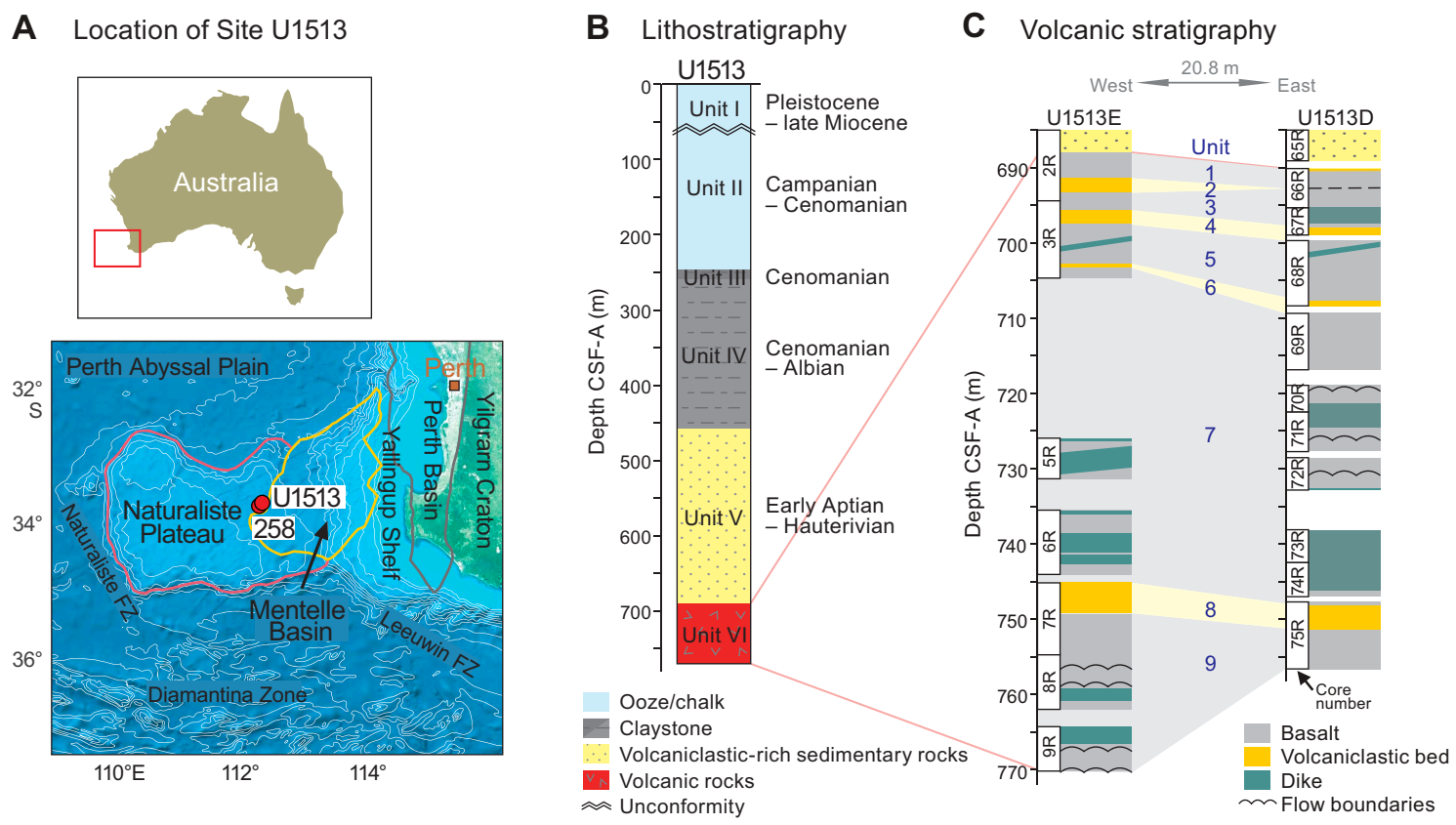

Table T1. X-ray diffraction mineral identification data of the volcanic sequence, Hole U1513D. Download table in CSV format.

Table T2. X-ray diffraction mineral identification data of the volcanic sequence, Hole U1513E. Download table in CSV format.

voltage of $40 \mathrm{kV}$, current of $40 \mathrm{~mA}$, and measurement range of $8^{\circ}-$ $80^{\circ} 2 \theta$. Mineral phases of the XRD data in all 44 core samples were identified using the X'pert HighScore Plus software at the Institut des Sciences de la Terre de Paris (ISTeP), Sorbonne University (France), and are listed in Tables T1 (Hole U1513D) and T2 (Hole U1513E). The XRD data of core samples from Hole U1513E are provided in XRD in Supplementary material.

\section{Results}

A total of 44 XRD data sets were analyzed to identify mineral phases in the volcanic sequence at Site U1513. These consisted of 25 data sets from basalt units, 12 data sets from dolerite dikes, and 7 data sets from the volcaniclastic units. Identified minerals are given in Table T1 for Hole U1513D and Table T2 for Hole U1513E. Previously available data were combined with the lithologic descriptions for systematic arrangement of petrology and volcanic stratigraphy (see details in Tejada et al., 2020). The XRD mineral data were significantly useful to establish the volcanic stratigraphy because the alteration hindered the core descriptions of primary lithology and lithological boundaries.

The primary mineralogy of the volcanic rocks at Site U1513 are olivine (mostly pseudomorphed), pyroxene, and plagioclase phenocrysts (Figure F2A) (Huber et al., 2019b; Tejada et al., 2020). The mineralogical composition of the dolerite dikes, dominated by plagioclase feldspar \pm pyroxene, is similar to the primary composi- tion of the basalt flows they intrude and the less altered basalts (Figure F2D). The dikes are relatively fresh, but when weakly altered they contain clay minerals related to the chlorite group (Tables T1, T2). In moderately altered basalts, secondary minerals replaced primary olivine and pyroxene phenocrysts, the Ca-rich cores of plagioclase feldspars, and the groundmass. In more advanced stages, secondary minerals also filled vesicles and formed alteration vugs and veins. Increasing alteration intensity, indicated by color, textural, and fabric changes (Tejada et al., 2020), is accompanied by higher amounts of clay minerals such as kaolinite, chlorite, smectite/chlorite mixed-layer minerals, and to a lesser extent smectite group minerals (probably montmorillonite) (Tables T1, T2). These group minerals likely represent the weathered products of minerals such as plagioclase feldspar and pyroxene. Chlorite contents increase in several intervals (e.g., in the volcanic flows of Units 7 and 9). Minor amounts of calcite-filled cavities and veins are present in some parts of the sequence (e.g., Section 369-U1513E-6R-7). In strongly altered basalts (e.g., Units 5 and 9), primary feldspars are pervasively replaced by clay minerals such as kaolinite (Figure F2B) or chlorite and iron oxides and oxyhydroxides such as hematite, magnetite, and goethite are present (Tables T1, T2). Traces of other alteration products such as serpentine and sericite are also possible, but the recognition of both phases, particularly for sericite, is complicated because their diffraction patterns are similar to those of clay and iron oxide minerals. Because sericitization occurs under high temperature and low $\mathrm{pH}$ conditions commonly resulting from hydrothermal activity (Mathieu, 2018), the presence of sericite indicates that the sequence may have undergone hydrothermal alteration, which is supported by calcite and hematite veins. Hydrothermal alteration and veins are also observed throughout the overlying volcaniclastic-rich sequence (Lithostratigraphic Unit V) (Lee et al., 2020). Hematization is observed throughout the sequence with variable intensity, although it is significantly intense in 
Figure F2. X-ray diffraction spectra and mineral identification of the volcanic sequence in Hole U1513E. A. Weakly altered basalt in Unit 1. B. Strongly altered basalt in Unit 5. C. Strongly altered volcaniclastic rock in Unit 6. D. Weakly altered dike in Unit 9. The details of the XRD data are presented in XRD in Supplementary material.
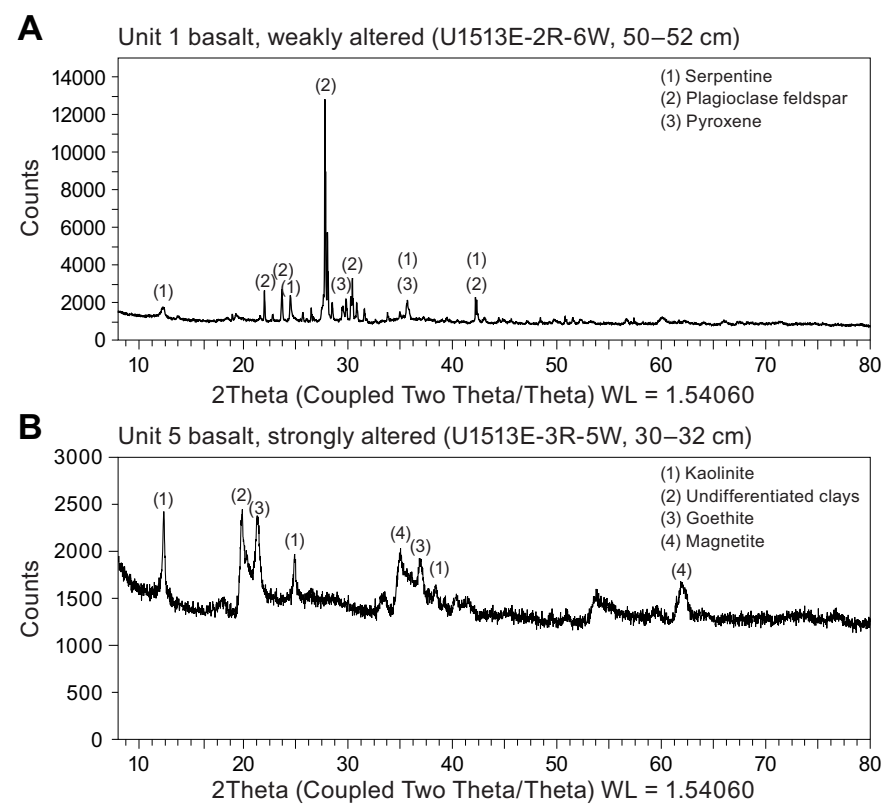

C Unit 6 volcaniclastics, strongly altered (U1513E-3R-7W, 130-132 cm)

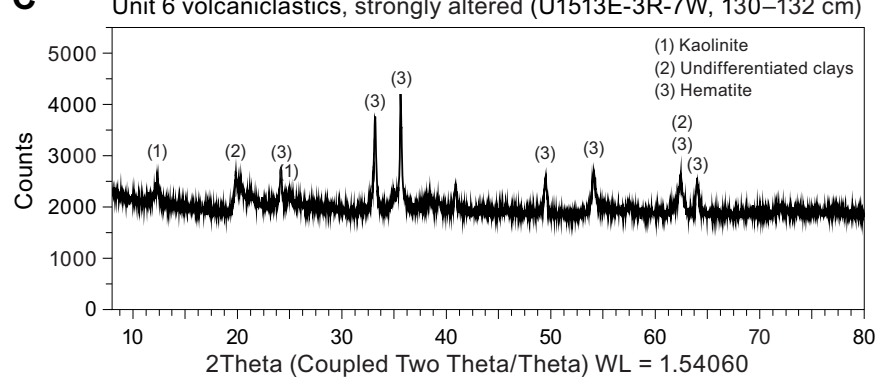

D

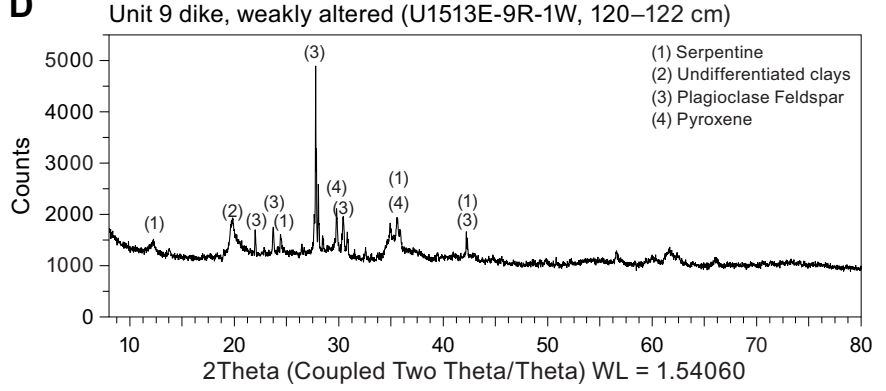

the volcaniclastic units (e.g., Units 4 and 6) (Figure F2C) and the upper part of the lowermost flows (Unit 9). The fine-grained matrix of the volcaniclastic beds contains clay minerals (mainly kaolinite mineral group and in some cases chlorite as well) and iron oxides (hematite and/or goethite) (Tables T1, T2).

\section{Acknowledgments}

This research used data and samples provided by the International Ocean Discovery Program (IODP). Funding for this research was provided by the European Consortium for Ocean Research
Drilling (ECORD) and IODP France to L.R., the K-IODP by the Ministry of Oceans and Fisheries and the Brain Pool Program by the Ministry of Science and Information and Communication Technology (ICT) through the National Research Foundation of Korea (NRF) (2017H1D3A1A01054745) to E.Y.L., and Japan Drilling Earth Science Consortium (J-DESC) to M.L.G.T. We thank the shipboard scientists and technical staff of IODP Expedition 369, especially Alexis Armstrong for XRD analysis and the crew members of the $\mathrm{R} / \mathrm{V}$ JOIDES Resolution for their critical contribution. Comments and suggestions by P. Pellenard improved this manuscript.

\section{References}

Borissova, I., 2002. Geological Framework of the Naturaliste Plateau: Canberra, Australia (Geoscience Australia). http://www.ga.gov.au/metadata-gateway/metadata/record/40535/

Huber, B.T., Hobbs, R.W., Bogus, K.A., Batenburg, S.J., Brumsack, H.-J., do Monte Guerra, R., Edgar, K.M., Edvardsen, T., Garcia Tejada, M.L., Harry, D.L., Hasegawa, T., Haynes, S.J., Jiang, T., Jones, M.M., Kuroda, J., Lee, E.Y., Li, Y.-X., MacLeod, K.G., Maritati, A., Martinez, M., O'Connor, L.K., Petrizzo, M.R., Quan, T.M., Richter, C., Riquier, L., Tagliaro, G.T., Wainman, C.C., Watkins, D.K., White, L.T., Wolfgring, E., and Xu, Z., 2019a. Expedition 369 methods. In Hobbs, R.W., Huber, B.T., Bogus, K.A., and the Expedition 369 Scientists, Australia Cretaceous Climate and Tectonics. Proceedings of the International Ocean Discovery Program, 369: College Station, TX (International Ocean Discovery Program). https://doi.org/10.14379/iodp.proc.369.102.2019

Huber, B.T., Hobbs, R.W., Bogus, K.A., Batenburg, S.J., Brumsack, H.-J., do Monte Guerra, R., Edgar, K.M., Edvardsen, T., Garcia Tejada, M.L., Harry, D.L., Hasegawa, T., Haynes, S.J., Jiang, T., Jones, M.M., Kuroda, J., Lee, E.Y., Li, Y.-X., MacLeod, K.G., Maritati, A., Martinez, M., O'Connor, L.K., Petrizzo, M.R., Quan, T.M., Richter, C., Riquier, L., Tagliaro, G.T., Wainman, C.C., Watkins, D.K., White, L.T., Wolfgring, E., and Xu, Z., 2019b. Site U1513. In Hobbs, R.W., Huber, B.T., Bogus, K.A., and the Expedition 369 Scientists, Australia Cretaceous Climate and Tectonics. Proceedings of the International Ocean Discovery Program, 369: College Station, TX (International Ocean Discovery Program). https://doi.org/10.14379/iodp.proc.369.104.2019

Lee, E.Y., Wolfgring, E., Tejada, M.L.G., Harry, D.L., Wainman, C.C., Chun, S.S., Schnetger, B., et al., 2020. Early Cretaceous subsidence of the Naturaliste Plateau defined by a new record of volcaniclastic-rich sequence at IODP Site U1513. Gondwana Research, 82:1-11. https://doi.org/10.1016/j.gr.2019.12.007

Mathieu, L., 2018. Quantifying hydrothermal alteration: a review of methods. Geosciences, 8(7):245. https://doi.org/10.3390/geosciences8070245

Riquier, L., Lee, E.Y., and Tejada, M.L.G, 2021. Supplementary material, https://doi.org/10.14379/iodp.proc.369.205supp.2021. Supplement to Riquier, L., Lee, E.Y., and Tejada, M.L.G., 2021. Data report: X-ray diffraction mineralogy of a volcanic sequence at Site U1513 (Naturaliste Plateau), IODP Expedition 369. In Hobbs, R.W., Huber, B.T., Bogus, K.A., and the Expedition 369 Scientists (Ed.), Australia Cretaceous Climate and Tectonics. Proceedings of the International Ocean Discovery Program, 369: College Station, TX (International Ocean Discovery Program). https://doi.org/10.14379/iodp.proc.369.205.2021

Tejada, M.L.G., Lee, E.Y., Chun, S.S., Harry, D.L., Riquier, L., and Wainman, C.C., 2020. Data report: petrology and volcanic stratigraphy at Site U1513, IODP Expedition 369. In Hobbs, R.W., Huber, B.T., Bogus, K.A., and the Expedition 369 Scientists (Ed.), Australia Cretaceous Climate and Tectonics. Proceedings of the International Ocean Discovery Program, 369: College Station, TX (International Ocean Discovery Program). https://doi.org/10.14379/iodp.proc.369.202.2020

Shipboard Scientific Party, 1974. Site 258. In Davies, T.A., Luyendyk, B.P., et al., (Ed.), Initial Reports of the Deep Sea Drilling Project, 26: Washington, DC (US Government Printing Office).

https://doi.org/10.2973/dsdp.proc.26.111.1974 